\title{
LONGEVITY AND ANNUITIES: AN INTRODUCTION
}

\author{
HELMUTH CREMER \\ Toulouse School of Economics (GREMAQ, IDEI, and Institut Universitaire de France) \\ PIERRE PESTIEAU \\ Université de Liège and CORE
}

For decades the debate on pensions has focused on the "accumulation phase" of the life-cycle. Many specific research topics have been explored as this literature has developed. However, they were all in one way or another concerned by the adequacy of saving. In other words, the main focus of the existing literature has been on the question of setting enough resources aside to keep the flow of consumption relatively stable after retirement. The main topics in this line have included the relative merits of pay-as-you go and funded pensions, the issue of early retirement in a world of increasing longevity and the threat of aging on the financial viability of pensions systems. It is only recently that some economists have started to be concerned by the "forgotten half" of retirement security: the "decumulation phase" (also called the "payout phase"). It is our belief that there both will and should be more research on this phase in the future.

Why should there be such a change in emphasis? A cynical answer would be that so much has been written on the relative merits of PAYGO and fully funded pensions, on the issue of privatizations, on the need of fostering activity rates of elderly workers, and so on, that pension economists are forced to seek new and unplowed fields. This is a rather negative view. We also see at least three positive reasons to explain the surge of interest in the decumulation phase: the continuing shift from "defined benefits" to "defined contributions" pensions both in the public and in the private sector, the thinness of the annuity market, and the demographic changes.

In countries like Germany or France, the main source of retirement income has for decades consisted of annuitized benefits from contributory pensions. In such a setting, one understands that the payout phase was not a big concern. The government provided a safe and adequate flow of resources

Helmuth Cremer, Toulouse School of Economics (IDEI and GREMAQ), 7, Bd Rectorat, 4000 Liège, Belgium (helmut@cict.fr). Pierre Pestieau, Université de Liège and CORE, 7, Bd Rectorat, 4000 Liège, Belgium (p.pestieau@ulg.ac.be).

Received July 29, 2009; Accepted July 30, 2009.

(C) 2010 Wiley Periodicals, Inc.

Journal of Public Economic Theory, 12 (1), 2010, pp. 1-5. 
during the full length of retirement. For better or for worse, these are becoming exceptional cases. In most countries we observe a continuous trend toward defined contributions pensions that offer at the time of retirement a lump sum capital without the obligation (or the appropriate incentives) of converting it into a flow of annuities.

Collective annuities that are associated with traditional social security systems are known to require relatively small loading factors. This is because they avoid the adverse selection trap of individual annuities and because they incur low administrative costs (at least in per contract terms). To some extent the same remarks apply to private defined benefit pensions. They offer annuities that are more attractive than those one can purchase on an individual basis. The reasons for the relative inefficiency of individual annuities are well known: thinness of the market, adverse selection, scale economies, etc. Some of them are discussed in this volume. The thinness of the annuity market can be explained by the paradoxical low demand for annuities, what is called the "annuity puzzle." Conversely the annuity puzzle can be explained by the thinness of the market and its ensuing inefficiency.

The third reason for this new concern for the decumulation side of pensions is demographic. Longevity increases, but so does the length of retirement, that is, the length of the decumulation phase. Furthermore, this increase is not accompanied by a decline in the uncertainty of mortality. Up to the age of 60 the rate of mortality has decreased in most industrialized countries, and survival until age 60 is becoming more and more certain. Beyond, the uncertainty of survival continues to be important.

This volume contains a selection of papers that were presented at the CESifo Venice Summer Institute held July 16-17, 2007, on the theme "Longevity and annuitization." In addition, it includes some papers that were submitted in reply to the call for paper papers published in this journal. Several papers are devoted to the issue of annuities. Others study the problems raised by an increase in longevity or by the fact that longevity varies across individuals and may even be endogenous (depend on individual and collective actions). There are also papers that deal with both questions. Finally, we include a paper that examines the behavioral dimension of pensions when individuals are myopic. Myopia here is about time preference but it could as well concern mortality prospects. We now present an overview of these contributions and start with those devoted to annuities.

\section{Annuities and Portfolio Choice}

The first paper, "Refundable annuities (annuity options)" by Eytan Sheshinski assumes that individuals cope with uncertainty about the length of life by purchasing annuities early in life. However, they also face other uninsurable contingencies (e.g., income risk). These situations create an active residual annuity market based on the arrival of new information over time. Sheshinski characterizes the equilibrium in the residual annuity market and proposes a new financial instrument, namely refundable annuities with a guaranteed 
refund price. This instrument enables individuals to better adjust their optimum consumption plan to different realizations. Refundable annuities are shown to be equivalent to annuity options, that is, options to purchase annuities later in life at a predetermined price. Holding a variety of refundable annuities is (ex ante) welfare enhancing.

In their paper "Collective annuities and redistribution," Helmuth Cremer, Jean Marie Lozachmeur, and Pierre Pestieau consider a society where individuals differ in both productivity and longevity, those two characteristics being positively correlated. The utilitarian first-best optimum is considered as a benchmark. It can be decentralized with individual actuarially fair annuities and lump-sum redistribution from short- to long-lived individuals and from high to low productivity individuals. The authors study the role of alternative pension systems that offer collective annuities (i.e., annuities that do not depend on individual survival probabilities). Within the context of linear pension schemes, a pure contributory (Bismarckian) pension and a flat rate (Beveridgean) pension are contrasted. It is shown that the case for collective annuities is stronger when they are associated with a flat pension system. Then nonlinear pension schemes are studied. It is shown that the solution can be implemented with pension payments that are in between individual and collective annuities. In other words, benefits do depend on life expectancy, but to a lesser degree than with actuarially fair private annuities.

In "Flexible life annuities" Alexis Drirer compares fixed annuities to flexible annuities from the viewpoint of social welfare. Flexible annuities offer subscribers the possibility to choose between different levels of annuities. In the case where agents gradually discover their actual probability of survival, a unique predetermined annuity plan is sufficient. However, when an expenditure risk is added to the longevity risk, a flexible annuity plan is better even though it is not sufficient to achieve a consumption path that is independent of uninsured expenses.

The paper "Portfolio choice under uncertain lifetime" by Antoine Bommier revisits the theory on life cycle savings and portfolio choice under uncertain lifetime emphasizing the role of temporal risk aversion. It provides new insights on the impact of mortality rates on optimal financial strategies. This is of particular interest for the management of pension funds and is at odds with findings based on the traditional temporal risk neutrality implicit in standard models à la Yaari, Merton or Samuelson. For instance, temporal risk aversion implies that optimal financial strategies should depend on mortality rates. Consequently, pension-fund managers should revise their financial strategies in response to the evolution of longevity. Furthermore, they should provide pensions that are indexed on more or less risky funds, according to an individual's age.

Hippolyte d'Albis and Emmanuel Thibault in "Annuities; bequests and portfolio diversification," analyze the diversification motives of the demand for annuities. In a model allowing for the uncertainty of longevity and interest rate, the individual is assumed to choose an optimal portfolio to maximize a 
bequest. The authors derive and discuss the conditions under which an increase in the risk of bond returns increases the demand for annuities. Moreover, they show that, contrary to previous claims, more risk aversion may be associated with a lower demand for annuities.

\section{Variable Longevity and Public Policy}

A second series of papers deals with the issue of variable and possibly endogenous longevity and its consequences for public policy.

In his paper, "Unequal longevities and lifestyles transmission," Gregory Ponthiere is concerned by the design of optimal taxation when longevity is endogenous. Unequal longevities result from differences in lifestyles and the composition of the population regarding different lifestyles is endogenously determined. In other words, Ponthiere assumes that unequal longevities are the unintended outcome of differences in lifestyles and that lifestyles are transmitted across generations. This is in sharp contrast with traditional taxation under heterogeneous longevity models that assume fixed heterogeneity of lifestyles. He develops a three-period OLG model where the population, who ignores the negative impact of excessive work on longevity, is partitioned in two groups with different tastes for leisure, and follows an adaptation/imitation process à la Bisin and Verdier (2001). The optimal shortand long-run (Pigouvian) taxes on wages are shown to differ. This is because the long-run tax corrects agents' myopia. In addition, it internalizes intergenerational externalities due to the socialization process.

Mathias Kifmann in his paper "The design of pension pay out options when the health status during retirement is uncertain" examines the optimal pension schemes when health during retirement is uncertain and influences both longevity and the marginal utility of consumption. The main finding is that the possibility of opting between annuities and lump-sum payment at the time of retirement may be welfare enhancing if the health status is not observable. Such a welfare improvement occurs when the marginal utility of consumption and life expectancy are negatively correlated.

The paper "The political economy of social security under differential mortality and voluntary retirement" by Marie-Louise Leroux looks at the pension system that would be chosen by a majority of individuals in a setting wherein individuals differ in longevity and choose their age of retirement. The main conclusion is that the majority equilibrium implies a positive public pension when longevity density is left-skewed. It also appears that the generosity of the system increases with the average level of longevity.

In "On optimal lifetime redistribution policy" Sanna Tenhunen and Matti Tuomala examine various aspects of the optimal lifetime redistribution policy when individuals differ not only in productivity, but also in time preference. Given the complexity of the analysis they use both an analytical and a numerical approach. Their results provide a rationale for distortions (upward and downward) in savings behavior in a simple two-period model where 
high-skilled and low-skilled individuals have different nonobservable time preferences. The numerical results suggest that retirement consumption is less dispersed than the first-period consumption in a paternalistic case. Paternalistic policy also increases second-period consumption compared to the welfarist case.

\section{Reference}

BISIN, A., and T. VERDIER (2001) The economics of cultural transmission and the dynamics of preferences, Journal of Economic Theory 97, 298-319. 
Copyright of Journal of Public Economic Theory is the property of Blackwell Publishing Limited and its content may not be copied or emailed to multiple sites or posted to a listserv without the copyright holder's express written permission. However, users may print, download, or email articles for individual use. 